\title{
Benjamin Dawson Porritt, M.Sc., F.I.C., F.Inst.P., F.I.R.
}

Benjamin Dawson PorRitT died at Croydon on January 28, I940, at the age of fifty-six years. The only son of the late Herbert Thomas Porritt of Armley, Yorkshire, he was born in Canada and educated at Whitgift Grammar School, Croydon.

He studied at University College, London, from 1903 to I906, graduating B.Sc. in 1906, and subsequently proceeded to M.Sc. After a year on research with Sir William Ramsay and Professor Norman Collie, he was appointed chemist to the North British Rubber Company, Edinburgh, with whom he remained until 1920, being appointed chief chemist in 1912 and research superintendent in 1916. During this period he carried out valuable work for the fighting services in the War of 19I4-I8.

When, in 1920, the British rubber manufacturers decided to set up a co-operative industrial research association under the scheme introduced by the Department of Scientific and Industrial Research, Porritt became Director of the Research Association of the British Rubber and Tyre Manufacturers, a position which he occupied until his death. The building up of the new research organisation and its guidance during a period beset with difficulties was a task for which Porritt was well fitted, and he devoted himself to it with unsparing energy and perseverance.

He was the author of many scientific and technical papers relating to rubber and of a monograph on The Chemistry of Rubber.

Porritt was elected a Fellow of this Society in I919. He was a Fellow of the Institute of Chemistry, a Fellow and Vice-President of the Institution of the Rubber Industry, and a Fellow of the Institute of Physics. $\mathrm{He}$ served on the councils of the Institute of Chemistry, the Institution of the Rubber Industry, and the Chemical Society. In 1938 he was awarded the Colwyn Medal.

A keen member of the Rugby Fifteen at University College, he retained his interest in Rugby all his life, but his main recreation was to get out with one or two friends in a small yacht and potter round the coast.

A man of genial disposition and invariable good nature, Porritt had a multitude of friends. He leaves a widow and two daughters.

A. C. C. 